\title{
Influence of treatment with pancreatic extracts on pancreatic enzyme secretion
}

\author{
J MÖSSNER, H P WRESKY, W KESTEL, J ZEEH, U REGNER, \\ AND W FISCHBACH \\ From the Medizinische Poliklinik, University of Würzburg, Würzburg, Federal Republic of Germany
}

SUMmary We have evaluated the effects of porcine pancreatic extracts on human pancreatic secretion. Ten male volunteers were intubated with a 4-lumen jejunal tube to collect gastric and duodenal secretions separately via the first and third tube, to infuse PEG 4000 distal the pylorus via the second tube and to apply porcine pancreatic extracts via the fourth tube distal the ligament of Treitz. Pancreatic extracts were given four times at $\mathbf{4 0}$ minute intervals; the first two as active enzymes and subsequently as heat denatured proportions. Secretin was continuously infused intravenously $(0.5 \mathrm{E} / \mathrm{kg} \mathrm{bw} / \mathrm{h})$ to achieve minimal pancreatic flow. Lipase, amylase, trypsin, chymotrypsin, volume, and bicarbonate were measured in duodenal contents in eight pooled 15 minute fractions. Three subjects who received HEPES-Ringer buffer instead of pancreatic enzymes served as controls. Plasma cholecystokinin (CCK) was measured using a sensitive bioassay. Both active and heat denatured pancreatic extracts caused a small but significant increase in amylase and chymotrypsin secretion. Basal plasma CCK values were $0.85(0.05)$ pM. After intrajejunal instillation of either active or heat denatured pancreatic extracts plasma CCK rose to $3 \cdot 25(0 \cdot 30) \mathrm{pM}$ and to $3 \cdot 28(0 \cdot 36) \mathrm{pM}$ respectively. In a second group of five volunteers, plasma CCK concentrations were measured after a test meal. On day 1 , volunteers received a liquid fat and protein rich meal and on day 2 , the same test meal containing porcine pancreatic extracts. In both cases, a similar increase in plasma CCK was observed. We conclude that therapy with pancreatic extracts stimulate pancreatic enzyme secretion. This may be mediated through release of CCK.

Regulation of pancreatic enzyme secretion by pancreatic proteases in the duodenum via a negative feedback has been shown in a number of studies in rats, ${ }^{1-3}$ chicken, ${ }^{4}$ and pigs. ${ }^{5}$ In rats this negative feedback control is clearly mediated through CCK. ${ }^{-n}$ The findings in man are more controversial. In the absence of nutrients, pancreatic secretions did not exert a negative feedback on human pancreatic secretions. ${ }^{4}$ Furthermore, in other studies, inhibition of intraduodenal trypsin did not stimulate pancreatic secretion. ${ }^{111}$ Other groups, however, reported feedback regulation of human pancreatic secretion by trypsin. ${ }^{2-14}$ Studies on patients with chronic pancreatitis seemed to further support the hypothesis that negative feedback regulation exists in man. In this disease, which sooner or later leads to a decrease of pancreatic protease secretion, raised plasma CCK

Address for correspondence: Priv Doz Dr med Joachim Mössner, Medizinische Poliklinik, University of Würzburg. Klinikstr $8,87(0)$ Würzburg. FRG.

Accepted for publication 8 December 1988. concentrations have been reported. ${ }^{15}$ is Treatment with pancreatic enzymes caused a reduction of pain which was considered to be the result of lowering the intraductal pressure by intraluminal trypsin. ${ }^{17}$ Others, however, could neither confirm raised CCK concentrations in advanced chronic pancreatitis nor could they confirm a lessening of pain when patients were treated with pancreatic enzymes. ${ }^{11}{ }^{19}$

In the present study, we investigated the effects of porcine pancreatic extracts on pancreatic enzyme secretion and on plasma CCK of healthy volunteers. The aim was to clarify whether commercially available capsules of pancreatic enzymes, given in a dosage known to be effective in pancreatic insufficiency, are able to inhibit pancreatic secretion.

Methods

MATERIA LS

The following chemicals were used: $\mathrm{N}-2$ - 
hydroxyethyl-piperazine- $\mathrm{N}^{\prime}$-2-ethanesulfonic acid (HEPES), ethylenediaminetetraacetic acid, partially purified lyophilised enterokinase, porcine pancreatic lipase (type IV-S), porcine pancreatic amylase (type $\mathrm{VI})$, porcine pancreatic trypsin (type IX), soybean trypsin inhibitor (type I-S), cholecystokinin octapeptide $\left(\mathrm{CCK}_{8}\right)$, gum arabic, bovine plasma albumin (fraction V) from Sigma Chemical, St Louis, MO; chromatographically purified collagenase (type CLSPA) from Cooper Biomedical, Wiesbaden, FRG; polyethylene glycol 4000 (PEG), trichloroacetic acid, zincsulfate, phenol red, indigocarmin, acetonitrile from Merck, Darmstadt, FRG; BioRad protein assay from Bio-Rad Laboratories, Richmond, CA; octadecylsilylsilica (SEP-Pak C-18) cartridges from Water Associates, Milford, MA; synthetic secretin $\left(\right.$ Sekretolin $\left.{ }^{R}\right)$ from Hoechst, Frankfurt, FRG; aprotinin $\left(\right.$ Trasylol $\left.^{R}\right)$ from Bayer, Leverkusen, FRG; Whatman 42 ashless filters from W\&R Balston Lim, UK; and minimal Eagle's medium amino acid supplement from Biochrom KG, Berlin, FRG. Panzytrat ${ }^{\mathrm{R}} 20000$ was a gift from Nordmark Arzneimittel GMBH, Uetersen, FRG. All other reagents had the highest purity grade commercially available.

SUBJECTS

Twenty healthy male volunteers, 19-26 years participated in the studies. All subjects were within $10 \%$ of their ideal body weight. None were taking any medication, or had any history of gastrointestinal diseases. The studies were approved by the Commission for Ethics at the University of Würzburg.

INTRADUODENAL/JEJUNAL, PERFUSION

STUDIES

All studies were performed after an overnight fast. A four lumen polyvinyl tube was placed under fluoroscopic control. Gastric secretions were continuously aspirated through the first lumen with the tube situated at the gastric antrum using an automatic pump (Ochler \& Braun, Stuttgart, FRG). Polyethylene glycol $4000(15.0 \mathrm{~g} / \mathrm{l} ; 3 \mathrm{ml} / \mathrm{min})$ was infused through the second lumen just distal the pylorus. Duodenal secretions were aspirated through the third tube by continuous suction (suction pressure varying from 0 to $400 \mathrm{mmHg}$ ) with the aspiration holes of the tube $15-25 \mathrm{~cm}$ distal the PEG infusion site. Pancreatic extracts were given distal the ligament of Treitz through the fourth tube $30 \mathrm{~cm}$ distal the last duodenal aspiration site.

A new preparation of acid protected commercially available porcine pancreatic enzymes was applied in a dosage commonly used for treatment of pancreatic insufficiency ${ }^{211} \quad\left(\right.$ Panzytrat $\left.^{\mathrm{R}} 20000\right)$, capsules with microtablets, containing per capsule according to the information provided by the manufacturer, triacylglycerollipase $20000 \mathrm{Ph}$ Eur-U, amylase $18000 \mathrm{Ph}$ Eur-U, proteases $1000 \mathrm{Ph}$ Eur-U). For our studies, three capsules Panzytrat ${ }^{\mathrm{K}} 20000$ were homogenised by Ultraturax ${ }^{\mathrm{R}}$ in $20 \mathrm{ml}$ of a buffer containing 10 mM HEPES, $140 \mathrm{mM} \mathrm{NaCl}, 4.7 \mathrm{mM} \mathrm{KCl}, 1 \mathrm{mM}$ $\mathrm{NaHPO}_{4}, 1.13 \mathrm{mM} \mathrm{MgCl} 2,1.28 \mathrm{mM} \mathrm{CaCl}_{2}$, adjusted to $\mathrm{pH} 7 \cdot 4$. According to our own measurements, the activities of various pancreatic enzymes per $20 \mathrm{ml}$ buffer were as follows: trypsin $28.62(1.63) \mathrm{U}$ (in comparison, $20 \mathrm{mg}$ of pure porcine trypsin type IX obtained from Sigma Chemicals had an activity of $33.83(0.55) \mathrm{U})$; chymotrypsin $9.31(0.40) \mathrm{U}$; lipase $198.25(27.54) \mathrm{U}$; amylase 55900 (7738) U (mean (SE) for $\mathrm{n}=$ eight separate determinations).

Potential retroduodenal reflux of porcine pancreatic enzymes perfused intrajejunally was excluded by mixing the extracts with indigocarmin. Reflux could, therefore, be monitored visually when the dye appeared in the duodenal aspirations. The experiments were started between 7 and 8 am and a correct positioning of the tube was achieved at 11 am (1) h (time 0). Polyethylene glycol 4000 was continuously perfused $(15 \mathrm{~g} / \mathrm{l}$ physiological saline, $3 \mathrm{ml} / \mathrm{min})$ starting at time 0 . Duodenal contents were recovered by constant suction, collected on ice, and pooled at 15 minute intervals. Thirty minutes later a continuous intravenous low dose infusion of secretin was started to achieve minimal pancreatic flow (Sekretolin ${ }^{\mathrm{R}}, 0 \cdot 5$ $\mathrm{U} / \mathrm{min} / \mathrm{kg}$ body weight). At the same time three capsules of Panzytrat ${ }^{\mathrm{R}} 20000$ homogenised in $20 \mathrm{ml}$ HEPES-Ringer buffer were perfused through the fourth lumen within five minutes. After a further five minutes, duodenal contents were collected for $2 \times 15$ min (time 55 and 70 minutes). This schedule was repeated three times: pancreatic extracts perfused at times 70, 110, and 150 minutes, duodenal contents collected $80-110,120-150,160-190$ minutes. At times 110 and 150 , however, instead of perfusing active enzymes, the same amount of heat denatured Panzytrat ${ }^{\mathrm{R}} 20000$ solutions was used. In another group of volunteers the same procedure was repeated, but instead of starting with active enzymes heat denatured enzymes were given first, at times 30 and 70 minutes. A third group of three volunteers received instead of pancreatic extracts just HEPESRinger buffer (controls). In all three groups $20 \mathrm{ml}$ blood were collected at times $-5,10,25,35,50,65$, $75,90,105,115,130,145,155,170,185$ minutes for determination of CCK. Some voluntecrs had to be excluded due to reflux, non compliance or low recovery of PEG. A total of 13 completed the studies.

INFIUUENCEOFFOODANDPANCREATICEXTRACTS ON PI.ASMA CCK

Five volunteers received after an overnight fast a 
mixed liquid meal $(6 \mathrm{ml} / \mathrm{kg}$ bw) made of cream, milk, eggs, cacao and sugar $(41.5 \%$ fat, $17 \%$ protein, $41.5 \%$ carbohydrate $w / w$ ) which they had to drink within two minutes. Twenty millilitres blood were drawn 15 and one minute before and 7.5, 15, 30, 45 , and 60 minutes after feeding for determinations of CCK. This procedure was repeated with the same subjects the day after but with an additional application of microtablets from six capsules Panzytrat ${ }^{\mathrm{R}} 20000$.

\section{CHOLECYSTOKININ BIOASSAY}

Cholecystokinin was extracted from plasma using a modification of methods described by Liddle et al..$^{2122}$ Aprotinin was added to plasma samples (final concentration $400 \mathrm{U} / \mathrm{ml})$. Plasma was diluted with icecold $2 \%$ trifluoroacetic acid (TFA) (1:4). CCK was extracted by adsorption on SEP-PAK cartridges previously washed with $10 \mathrm{ml}$ acetonitrile and $10 \mathrm{ml}$ $0 \cdot 1 \%$ TFA. The cartridges were then washed again with $10 \mathrm{ml} 0 \cdot 1 \%$ TFA and the CCK was eluted with $2 \mathrm{ml}$ of acetonitrile/ $0 \cdot 1 \%$ TFA $(1: 1)$. The eluates were collected in flat bottomed incubation vials and dried under a nitrogen stream at $45^{\circ} \mathrm{C}$ and stored at $-70^{\circ} \mathrm{C}$. These vials were subsequently used for incubation with $1 \mathrm{ml}$ of acini suspensions.

PREPARATION OF ISOLATED PANCREATIC ACINI Pancreatic acini were prepared from male Sprague Dawley rats (150-250 g) by digestion of pancreatic tissue $(0 \cdot 8-1 \cdot 3 \mathrm{~g})$ with purified collagenase at $37^{\circ} \mathrm{C}$ in an agitating water bath as described in the literature..$^{23}$ After digestion the acini were dissociated by up-and-down suction through polypropylene pipettes with restrictive orifices, filtered through a $150-\mu \mathrm{m}$ nylon cloth, and further purified by centrifugation through a $4 \%$ albumin gradient. Thereafter, the acini were suspended in a buffer containing 40 $\mathrm{mM}$ Tris (hydroxymethyl) aminomethane, $103 \mathrm{mM}$ $\mathrm{NaCl}, 1 \mathrm{mM} \mathrm{NaHPO} 4,4 \cdot 7 \mathrm{mM} \mathrm{KCl}, 1.28 \mathrm{mM} \mathrm{CaCl}_{2}$, $0.56 \mathrm{mM} \mathrm{MgCl}_{2}, 11.1 \mathrm{mM}$ glucose, $0.1 \mathrm{mg} / \mathrm{ml}$ soybean trypsin inhibitor, enriched with minimal Eagle's medium amino acid supplement, and $5 \mathrm{mg} / \mathrm{ml}$ bovine plasma albumin. This buffer was equilibrated with $100 \% \mathrm{O}_{2}$ and adjusted to $\mathrm{pH} 7 \cdot 4$. The average acinar protein concentration was in the range of $0.2-$ $0.5 \mathrm{mg} / \mathrm{ml}$.

Isolated acini were then incubated with either plasma extracts or various concentrations of $\mathrm{CCK}_{8}$ for $30 \mathrm{~min}$ at $37^{\circ} \mathrm{C}$ and the release of amylase monitored. Amylase release, expressed as percentage of total amylase activity, was compared with a dose response curve for $\mathrm{CCK}_{8}$ in order to calculate the $\mathrm{CCK}$ content of plasma expressed as $\mathrm{CCK}_{8}$ equivalents. Preparations of rat pancreatic acini have shown the typical biphasic dose response curve to
$\mathrm{CCK}_{8}$. The threshold dose was between $1-3 \mathrm{pM}$ and maximal secretion was seen at $30-100 \mathrm{pM}$.

ASSAYS

Amylase activity for bioassays of CCK was assayed in pancreatic homogenates and supernatants using procion yellow as substrate. ${ }^{25}$

Protein was measured according to the method of Bradford using the Bio- $\mathrm{Rad}$ reagent. ${ }^{2 h}$

Measurement of pancreatic enzymes in duodenal contents: trypsin activity was assayed using an enzymatic colorimetric test with benzoylarginine-pnitroanilide as the substrate (test combination, Boehringer Mannheim, FRG). ${ }^{27}$ Chymotrypsin activity was assayed using a colorimetric enzyme assay with $\mathrm{N}$-(3-carboxypropionyl)-phenylalanine-pnitroanilide as the substrate (Boehringer, Mannheim, FRG). ${ }^{2 *}$ Lipase and amylase activity were assayed using a nephelometric method with purified olive oil as the substrate for lipase and amylopectin for amylase ${ }^{24}$.31) (Perkin-Elmer Model 91 Amylase-Lipase-Analyzer, Perkin-Elmer, Oak Brook, III). Bicarbonate was measured via back titration with $0.1 \mathrm{M} \mathrm{NaOH}$ with phenol red as indicator. Polyethylene glycol was measured turbidometrically according to the methods described by Hyden et al $^{31}$ and Malawer et al. ${ }^{32}$

Statistical analysis was performed using analysis of variance, paired, and unpaired $t$ test with the acceptance criteria of $p=0 \cdot 05$. All results were expressed as mean (SE).

\section{Results}

EFFECT OF PORCINE PANCREATIC EXTRACTS ON HUMAN PANCREATIC SECRETION

Commercially available porcine pancreatic extracts, used for treatment of human pancreatic insufficiency, were applied in the upper jejunum and secretion of bicarbonate and endogenous pancreatic digestive enzymes measured. When compared with perfusion of the upper jejunum with Hepes-Ringer buffer alone, pancreatic enzymes caused a small but statistically significant increase of amylase and chymotrypsin secretion but not of trypsin and lipase (Fig. 1). The proteases contained in the enzyme capsules did not cause any decrease of endogenous non-food stimulated enzyme secretion when compared with controls. When pancreatic extracts were heat denatured before their jejunal application, a small but significant increase of secretion of amylase and chymotrypsin was again seen but none for trypsin and lipase (Fig. 1). When the effect of active enzymes on pancreatic secretion was compared with the effect of inactive ones in the same volunteer, many subjects showed a lower enzyme secretion after the applica- 

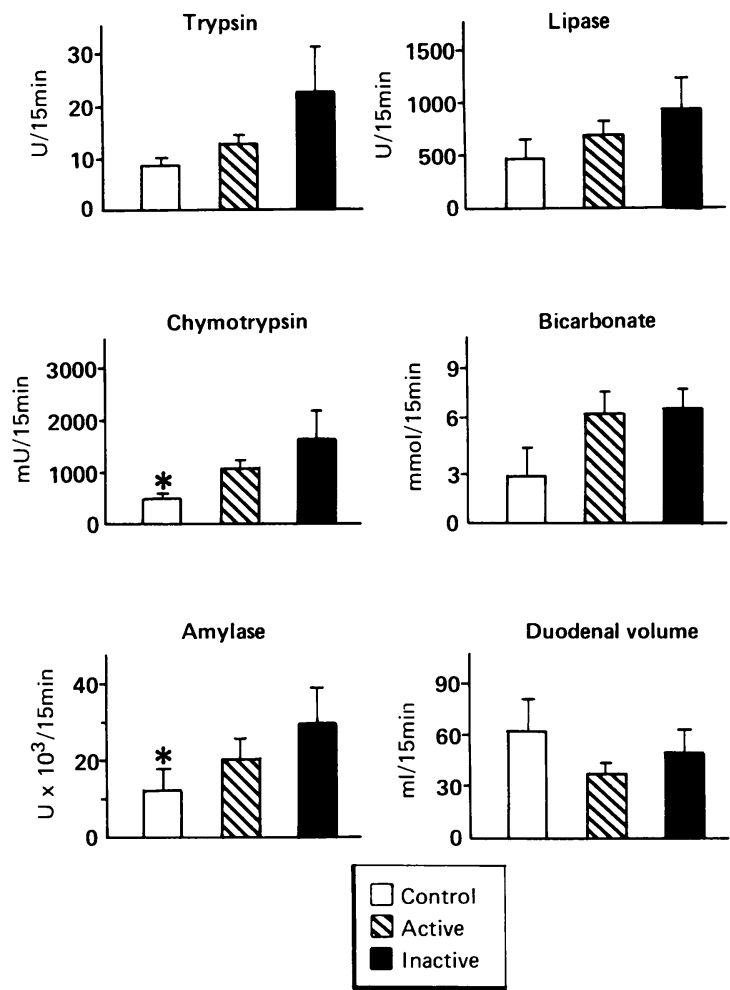

Fig. 1 Influence of porcine pancreatic extracts on pancreatic secretion. Ten male volunteers received four times pancreatic extracts intrajejunally, the first two times as active enzymes followed by the application of the same amount of heat denatured extracts or vice versa, and duodenal contents were collected to measure output of pancreatic enzymes. Three volunteers received HEPES-Ringer buffer instead of pancreatic extracts (control). The mean of four $15 \mathrm{~min}$ duodenal fractions per subject was formed after either active or inactive extracts, as well as from eight 15-min fractions per control subject. Bars show the mean (SE) of the data from all subjects. Asterisk displays a statistically significant difference between control and both active and inactive extracts.

tion of active enzymes. Trypsin for example, was lower in eight of 10 subjects after the application of active enzymes as compared with inactive ones (Fig. 2). Chymotrypsin was lower in eight, amylase in six, and lipase in five subjects (data not shown). Because of considerable variations in pancreatic secretion between different subjects, however, neither the means of enzyme activities in each 15 min fraction (data not shown) nor of the pooled $15 \mathrm{~min}$ fractions (Fig. 1) showed any statistically significant differences.

EFFECT OF PANCREATIC DIGESTIVE ENZYMES ON PLASMA CCK

Basal plasma CCK, determined at times $-5,10$, and

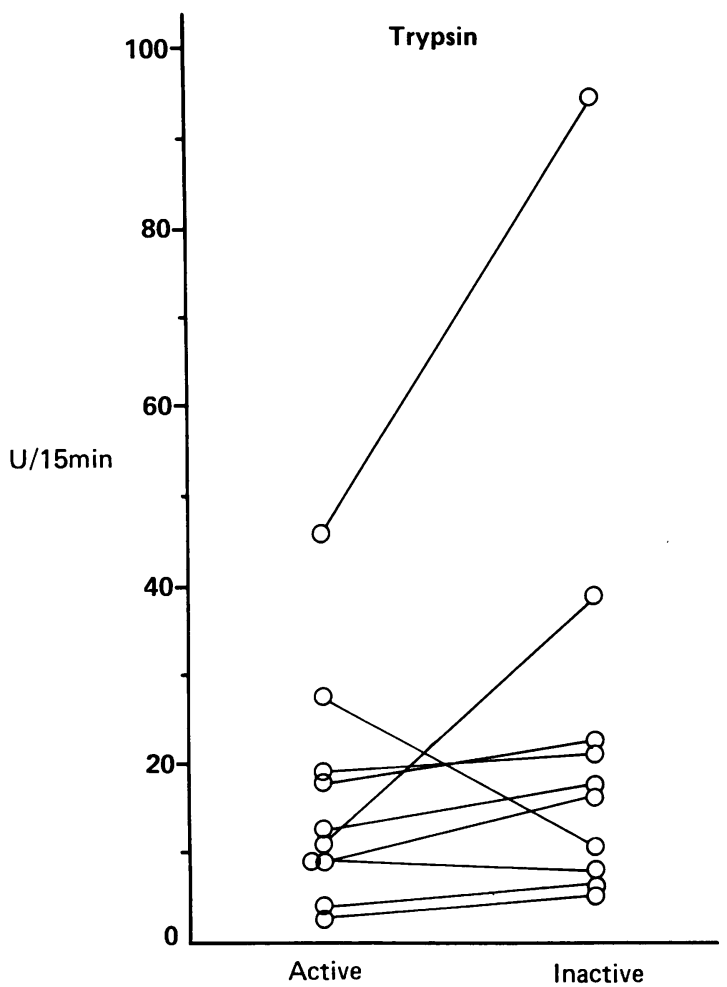

Fig. 2 Influence of active versus inactive porcine pancreatic extracts on trypsin output. The mean of the trypsin activity from four 15 min duodenal fractions from subjects of Figure $l$ is compared intraindividually after the application of either active or inactive extracts.

25 min, was $0 \cdot 85(0 \cdot 05) \mathrm{pM}$ (mean (SE); CCK was determined at each time point in duplicate) in subjects who received later pancreatic extracts $(\mathrm{n}=10)$ and $1.33(0.17) \mathrm{pM}$ in volunteers who received HEPES-Ringer buffer $(n=3)$. The difference was not statistically significant. Application of HEPES-Ringer buffer did not cause any statistically significant changes in plasma CCK $(1 \cdot 31(0 \cdot 11) \mathrm{pM})$ (Fig. 3). Both active as well as heat denatured porcine pancreatic enzymes, when applied intrajejunally, however, caused a small but statistically significant and comparable increase in plasma CCK (Fig. 3). Integrated plasma CCK was $3.25(0 \cdot 30) \mathrm{pM}$ after active enzymes and $3.28(0 \cdot 36)$ after inactive ones.

PLASMA CCK AFTER INGESTION OF FOOD WITH OR WITHOUT SIMULTANEOUS APPLICATION OF PANCREATIC ENZYMES

Ingestion of food caused a rapid and sustained increase of plasma CCK (Fig. 4). The addition of six 


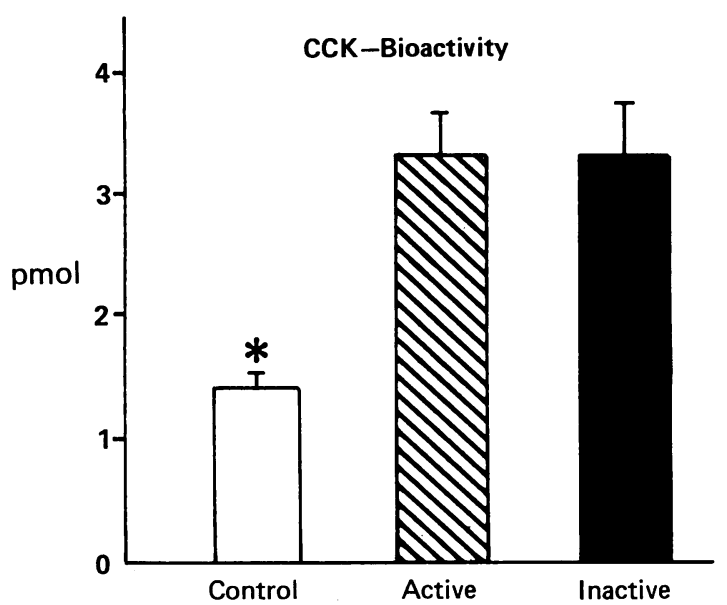

Fig. 3 Influence of active and inactive pancreatic extracts on plasma CCK. Plasma CCK was measured via bioassay. Bars show the mean ( $S E$ ) of integrated plasma $C C K$ values of the thirteen subjects from Figure 1. Asterisk displays a statistically significant difference between control, and both active and inactive.

capsules of Panzytrat ${ }^{\mathrm{R}} 20000$ to the liquid meal did not cause a different pattern of plasma CCK (Fig. 4).

\section{Discussion}

Pain in patients suffering from chronic pancreatitis may be caused by a rise of pressure in pancreatic ducts. ${ }^{33}$ A reduction of pressure via an inhibiton of pancreatic secretion could, therefore, reduce pain. There are now many studies supporting the hypothesis of negative feedback regulation of human pancreatic secretion by proteases. ${ }^{12-1+}$ With the application of proteases, therefore, one should be able to inhibit pancreatic secretion. Patients with pancreatic insufficiency are usually treated with porcine pancreatic extracts which contain a mixture of digestive enzymes. At present, acid protected tablets with high amounts of lipase are preferred in the treatment of pancreatic insufficiency."2 In this study we investigated whether acid protected porcine pancreatic extracts in a dosage known to be successful in the treatment of pancreatic insufficiency, given either alone or together with a meal, are able to inhibit pancreatic secretion. In an experimental design in man, however, one can not apply porcine pancreatic enzymes orally or perfuse intraduodenally and measure secretion of endogenous pancreatic enzymes simultaneously. In the studies reported by Slaff et al, ${ }^{12}$ therefore, enzyme therapy was discontinued the day before pancreatic secretion was measured. In this design, however, one can not measure acute effects of pancreatic extracts on pan-

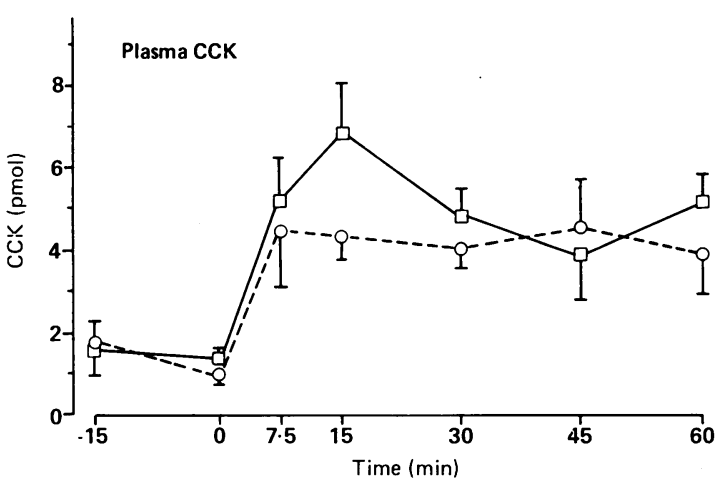

Fig. 4 Effect of food containing active pancreatic extracts on plasma CCK. Five subjects received at times $O$ a liquid meal. Values show the mean (SE) of plasma CCK at various times (interrupted line). Same subjects received on day two a similar liquid meal containing six capsules of pancreatic extracts (Panzytrat $\left.{ }^{\mathrm{R}} 20000\right)$ (uninterrupted line).

creatic secretion. In the study reported by Owyang et al only pure enzymes, and not a combination of digestive enzymes, were perfused intraduodenally. It may be possible that the amount of other proteins present in pancreatic extracts overwhelms a potential inhibitory effect of proteases. We, therefore, perfused the upper jejunum with pancreatic extracts which enabled us to measure the effect on pancreatic secretion. Both active pancreatic extracts and heat denatured enzymes caused a small increase in plasma CCK and an increase in secretion of chymotrypsin and amylase when compared with controls. Comparing the effect of active extracts on pancreatic secretion with inactive ones, it was not possible to show a statistically significant inhibition of pancreatic enzyme secretion. We next added those extracts to food. With this experimental design it is not possible to measure endogenous secretion because pancreatic secretions cannot be diverted. Therefore, plasma CCK was measured assuming that the level of CCK displays a strong correlation to pancreatic secretion. The addition of active pancreatic extracts to food did not cause a lower increase in plasma CCK. Thus, we could not show feed back regulation of enzyme secretion with doses of pancreatic extracts commonly used in clinical medicine.

Perfusing the duodenum with trypsin, Owyang et al clearly showed an inhibition of phenylalanine, oleic acid, and meal stimulated chymotrypsin and lipase output. ${ }^{13}$ The amount of trypsin they used to inhibit pancreatic secretion, however, was rather high, 150$300 \mathrm{mg}$ bovine type III S, within one hour. ${ }^{13}$ The trypsin activity per tablet of porcine pancreatic extracts available in West Germany ranges between 800 and 2000 FIP Units. According to our own 
measurements with regards to Panzytrat ${ }^{\mathrm{R}} 20000$, which contains 1000 FIP, one capsule corresponds approximately to $6 \mathrm{mg}$ trypsin (porcine type IX, Sigma). According to the data of Owyang et al 25-50 capsules per meal would have to be used to achieve inhibition of secretion. In the study reported by Slaff et $a l$, protease specific suppression of pancreatic exocrine secretion was also seen only with very high doses of trypsin.'2 It may be assumed that trypsin binds to food. Thus high levels of trypsin were needed in the studies reported by Owyang et a $l^{13}$ and Slaff $e t a^{12}$ to overcome the binding of trypsin to food so that sufficient trypsin is present to exert negative feedback. Proteases in very high concentrations in the presence of food and in may be lower concentrations in the absence of food may be capable, therefore, to inhibit human pancreatic secretion. Pancreatic extracts, however, given in a dosage commonly used in clinical medicine do not inhibit, but rather stimulate pancreatic secretion. This may be because of the high protein content of enzyme capsules. We doubt, therefore, that pain in chronic pancreatitis can be treated via an inhibition of pancreatic secretion by the application of pancreatic extracts commercially available at present.

This study was supported by a grant of the Deutsche Forschungsgemeinschaft (Mo 372/2-1). Some of the results are part of the MD thesis of H P Wresky. Parts of the study have been published as abstract. ${ }^{3+}$ The authors thank Mrs S Stieber, Mrs L Kneis, and Mrs G Gebert for expert technical assistance.

\section{References}

1 Green GM, Lyman RL. Feedback regulation of pancreatic enzyme secretion as a mechanism for trypsin inhibitor-induced hypersecretion in rats. Proc Soc Exp Biol Med 1972; 140: 6-12.

2 Ihse I, Lilja P. Lundquist I. Trypsin as a regulator of pancreatic secretion in the rat. Scand J Gastroenterol 1979; 13: 873-80.

3 Miyasaka K, Green GM. Effect of partial exclusion of pancreatic juice on rat basal pancreatic secretion. Gastroenterology 1984; 86: 114-9.

4 Chernick SS, Lepkovsky S, Chaikoff IL. A dietary factor regulating the enzyme content of the pancreas: changes induced in size and proteolytic activity of the chick pancreas by ingestion of raw soybean meal. Am J Physiol 1948; 155: 33-41.

5 Corring T. Mechanisme de la secretion pancreatique exocrine chez le porc: regulation par retro inhibition. Ann Biol Anim Biochim Biophys 1973; 13: 755-6.

6 Fölsch UR, Cantor P, Wilms HM, Schafmayer A, Becker HD, Creutzfeldt W. Role of cholecystokinin in the negative feedback control of pancreatic enzyme secretion in conscious rats. Gastroenterology 1987; 92: 499-58.
7 Louic DS, May D, Miller P, Owyang C. Cholecystokinin mediates feedback regulation of pancreatic enzyme secretion in rats. Am J Physiol 1986; 250: 252-9.

8 Lee PC. Newman BM, Praissman M, Cooney DR, Lebenthal E. Cholecystokinin: a factor responsible for the enteral feedback control of pancreatic hypertrophy. Pancreas 1986; 1: 335-40.

9 Krawisz BR, Miller LJ, DiMagno EP, Go VLW. In the absence of nutrients, pancreatic-biliary secretions in the jejunum do not exert feedback control of human pancreatic or gastric function. J Lab Clin Med 1980; 95: $13-8$.

10 Dlugosz J, Fölsch UR, Creutzfeldt W. Inhibition of intraduodenal trypsin does not stimulate exocrine pancreatic secretion in man. Digestion 1983; 26: 197204.

11 Hotz J, Ho SB. Go VLW, DiMagno EP. Short-term inhibition of duodenal tryptic activity does not affect human pancreatic, biliary, or gastric function. $J$ Lab Clin Med 1983; 101: 488-95.

12 Slaff J, Jacobson D, Tillman CR, Curington C, Toskes P. Protease-specific suppression of pancreatic exocrine secretion. Gastroenterology 1984; 87: 44-52.

13 Owyang C, Louic DS, Tatum D. Feedback regulation of pancreatic enzyme secretion. Suppression of cholecystokinin release by trypsin. J Clin Invest 1986; 77: 2042-7.

14 Ihse I, Lilja P, Lundquist I. Feedback regulation of pancreatic enzyme secretion by intestinal trypsin in man. Digestion 1977: 15: 303-8.

15 Funakoshi A, Nakano I, Shinozaki H. Tateishi K. Hamaoka T, Ibayashi H. High plasma cholecystokinin levels in patients with chronic pancreatitis having abdominal pain. Am J Gastroenterol 1986; 81: 1174-8.

16 Schafmayer A. Becker HD, Werner M, Fölsch UR, Creutzfeldt W. Plasma cholecystokinin levels in patients with chronic pancreatitis. Digestion 1985; 32: 136-9.

17 Isaksson $\mathrm{G}$, Ihse I. Pain reduction by an oral pancreatic enzyme preparation in chronic pancreatitis. Dig Dis Sci 1983; 28: 97-102.

18 Cantor P, Petronijevic L, Worning H. Plasma cholecystokinin concentrations in patients with advanced chronic pancreatitis. Pancreas 1986; 1: 488-93.

19 Halgreen H, Pedersen TN, Worning H. Symptomatic effect of pancreatic enzyme therapy in patients with chronic pancreatitis. Scand J Gastroenterol 1986; 21: 104-8.

20) Lankisch PG, Lembcke B, Kirchhoff S, Hilgers R, Creutzfeldt W. Treatment of pancreatogenic steatorrhea: a comparison of two acid-protected enzyme preparations. Dtsch Med Wochenschr 1988; 113: 15-7.

21 Liddle RA, Goldfine ID, Williams JA. Bioassay of plasma cholecystokinin in rats: effects of food, trypsin inhibitor, and alcohol. Gastroenterology 1984; 87: 542-9.

22 Liddle RA, Goldfine ID, Rosen MS, Taplitz RA, Williams JA. Cholecystokinin bioactivity in human plasma. J Clin Invest 1985; 75: 1144-52.

23 Williams JA, Korc M, Dormer RL. Action of secretagogues on a new preparation of functionally intact, isolated pancreatic acini. Am J Physiol 1978; 235: 517-24. 
24 Sankaran H, Iwamoto Y, Korc M, Williams JA, Goldfine ID. Insulin action in pancreatic acini from streptozotocin-treated rats. II. Binding of ${ }^{125}$ I-insulin to receptors. Am J Physiol 1981; 240: 63-8.

25 Jung DH. Preparation and application of procion yellow starch for amylase assay. Clin Chim Acta 1980; 100: 7-10.

26 Bradford M. A rapid and sensitive method for the quantitation of microgram quantities of protein utilizing the principle of protein-dye binding. Anal Biochem 1976; 72: 248-54.

27 Erlanger BF, Kokowsky N, Cohen W. The preparation and properties of two new chromogenic substrates of trypsin. Arch Biochem Biophys 1961; 95: 271-8.

28 Nagel W, Willig F, Peschke W, Schmidt FH. Über die Bestimmung von Trypsin und Chymotrypsin mit Aminosäure-p-Nitroaniliden. Hoppe Seylers Z Physiol Chem 1965; 340: 1.
29 Zinterhofer L, Wardlaw S, Jatlow PJ, Seligson D. Nephelometric determination of pancreatic enzymes. II Lipase. Clin Chim Acta 1973; 44: 173-8.

30 Zinterhofer L, Wardlaw S, Jatlow PJ, Seligson D. Nephelometric determination of pancreatic enzymes. I Amylase. Clin Chim Acta 1973; 44: 5-12.

31 Hyden S. A turbidometric method for the determination of higher polyethylene glycols in biological materials. Kungl Lantbrukshögsk Ann 1956; 22: 139-45.

32 Malawer SJ, Powell DW. An improved turbidometric analysis of polyethylene glycol utilizing an emulsificr. Gastroenterology 1967; 53: 250-6.

33 Wolfson P. Surgical management of inflammatory disorders of the pancreas. Surg Gynecol Obstet 1980; 151: 689-98.

34 Mössner J, Wresky H, Zeeh J, Regner U. Influence of treatment with pancreatic extracts on plasma cholecystokinin (CCK) and pancreatic enzyme secretion. Pancreas 1988; 3: 609. 